Függelék 



\title{
Költő László: Késő avar kori tárgyak röntgenemissziós analízise. Bölcsészdoktori értekezés bírálata (vázlat)'
}

\author{
LÁSZLÓ GYULA
}

Előre kell bocsájtanom, hogy az értekezés fémvizsgálati részeinek vizsgálatára nem vállalkozhatom, mert nem értek hozzá. De a vizsgálatok a Debreceni Atommagkutató Intézetben készültek az ottani kiváló kémikusokkal együttmúködve, s ez egymagában is biztosíték - nem is beszélve a szerző jó felkészültségéről és becsületes emberségéről -, hogy a dolgozat kémiai része a kor színvonalán áll, és a vizsgálat módszereinek teljes ismeretét tükrözi.

A téma időszerűségéröl. Régészetünk a "humán" módszerek tekintetében világszínvonalú, de állandóan érezzük, hogy természettudományos részről, különösen a kémia oldaláról nem kapunk olyan segítséget, mint a külföldi kollégák.

Nos, ebben kivétel a szerző, akinek kémiai mérnöki oklevele van, s azon kívül elvégezte egyetemünkön a régészeti szakot is. Kiváló munkakészsége és tehetsége megbecsülést biztosított számára már hallgató korában is.

Mi az, ami ebben a dolgozatában elöreviszi régészet-tudományunkat? Egyre inkább látjuk, hogy a késő avar (onogur) népnél az övnek nemcsak összefogó és tartó szerepe volt, hanem a szabad ember jelképe volt, és a rajta lévő veretek mintái nem csupán művészi kedvtelés eredményei, hanem rang- és méltóságjelzők voltak, és a veretek számának is jelentősége volt. Nos, e tekintetben például alapvető kérdés, hogy egy öv vereteit egyszerre szerelték-e rá az övre, vagy pedig egymás után kapta meg viselöjük a magasabb s magasabb rangját, s ennek megfelelően a veretek száma nőtt. Ezt külső szemmel eldönteni nagyon nehéz, bár látjuk, hogy az egyes veretek mintáiban kisebb eltérések vannak, tehát nem kerülhettek ki ugyanabból az öntőmintából. De itt a döntő szó az anyag összetétele. Ugyancsak döntő a felerősítő szögecsek anyaga. Nos, éppen ezeket a kérdéseket vizsgálja Költő László, s ezzel teljesen új eredményeket és új utakat nyit régészetünkben.

Ez a bírálat nem tǔzheti ki céljául az eredmények tallózó bemutatását, ez részletkérdés. A magam részéről úgy látom, hogy még egy aprósággal kiegészíthetők a vizsgálatok, bár ez nem az anyagot illeti, s így ebben a kitűnő doktori értekezésben nincs is keresnivalója. Ez pedig az övveretek felerősítése közben szenvedett esetleges torzulások, horpadások vizsgálata. Az érzékeny arany övvereteket pántokkal látták el, s ezeket átdugva a bőrbe vágott réseken, hátul összefúzték, majd az egész övet egy belső borító szíjjal takarták. Máshol az egész veretet átfogó kengyelt forrasztottak a veretekre, s úgy húzták rá a szíjakra. Amit Költő László vizsgál, az a harmadik módszer, amikor is az aklákkal ellátott szegecseket rákalapálták az övre. Költő írja is, hogy a szegecsek rendszerint puhább fémből készültek, s ennek így is kell lennie, mert egyébként a szegecsek fejére mért erős ütések, amelyek szétlapították a szegecsfejeket, könnyen tönkretehették volna magát a veretet is (feltehetőleg a vereteket faalapra tették szerelés közben, és az ütés így kevésbé ártott nekik).

A fentiekkel jeleztük, hogy ezek a látszólag „jelentéktelen” apróságok milyen mélyreható történeti kérdésekbe torkollanak. Érdekes - és tovább kutatandó - az a megfigyelése, hogy az öv különböző anyagú vereteinek szegecsei azonosak, tehát - így is magyarázható -, hogy egy-egy új veret felerősítésekor a többit leszedték, hogy az övre új rendben kerüljön fel valamennyi, az egyszer már elkalapált szegecsek hasznavehetetlenek lettek, s ezért kellett valamennyit új szegeccsel ellátni.

Költő külön fejezetet szentel az úgynevezett ezüstözésnek, ám ezek legtöbbje ólom és ón ötvözet volt, és igen magasrendú technológiát követelt. Ez megint új oldalról gazdagítja az avar kor technikai felkészültségét.

Költő végül is vizsgálatainak eredményeit temetőtérképekre vetítve értékeli, s így a „magyar iskola" temetőelemzéseit jelentős módon elmélyíti. De felveti például a bronz származásának kérdéseit is, vizsgálván eddig csak sejtett kapcsolatait a római kisbronzokkal.

1 A bírálat az MTA BTK László Gyula Digitális Archívumban maradt fenn (http://lgyda.btk.mta.hu/). Gépirat másolata, helyenként László Gyula kézírásos javításaival, aláírt példány. Itt is köszönjük László Zoltánnak, hogy a dokumentum publikálását engedélyezte számunkra. A szöveggondozás Szentpéteri József munkája. 
Tekintettel arra, hogy a hatalmas késő avar kori (onogur) leletanyagnak csak kis részét vizsgálhatta, a szerző természetesen csak óvatosan következtet. Általános érvényű megfigyelései közül kiemelendő, hogy vizsgálatai is megerősítik, hogy egy-egy nagyobb temetőben egyszerre több helyen indult meg a temetkezés - ez a történelem nyelvén annyit jelent, hogy egyszerre több nagycsalád vagy nemzetség lakott együtt, és a temetőben egyszerre több helyen kezdett temetkezni.

Érdekes megállapítás az is, hogy a késő avar bronzöntés alapanyaga csak nagyon ritkán egyezik meg a késő római bronzok anyagával, s így még Pannoniában sem számolhatunk a római bronzok nagyobb mértékű felhasználásával.

Mindent összevéve, ez a dolgozat jelentős mértékben előrevitte a késő avar kor kérdéseinek felvetését és az arra adott válaszok biztonságát. Sok-sok ilyen tanulmányra lenne szükség, hogy az eredményeket általánosítsuk, és közelebb juthassunk annak a művészettörténetileg is nagy jelentőségű leletcsoportnak megítéléséhez, amit a „griffes-indás kör" Európában jelent.

Kívánatos lenne Költő László további munkásságának biztosítása (műszerezettség stb.), mert munkásságával régészetünk jobban felzárkózna az európai színvonalhoz. ${ }^{2}$

Az értekezést - a régészet részéről - kiemelten „summa cum laude” fokozattal fogadom el.

1982. XII. 10.

László Gyula

2 Eredeti szövegváltozat: „....munkássága felzárkózást jelent régészetünk európai helyzetében.” A kézírásos betoldással született végleges változat értelmezéséhez, feloldásához László Zoltán nyújtott segítséget. 


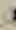
$+$

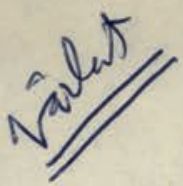

Lossutgos is Jootalk, es Mand in jebutivin net

$\Rightarrow$ tallóno
Költő László:Késő-avarkori t’́rgyak röntgenemissziós analizise.Bölcsészłoktori értekezés birálata.

Hốre kell bocsốjtanom, hogy az értekezés fémvizsgálati részeinek birálatára nem vállalkozhatom, mert nem értek hozzá. De a vizsgálatok a Debreceni tommag-kutató Intézetben készültek az ottani kiváló kémikusokkal együttmüködve s ez głmagában is biztositék-nem is beszélve a szerzố jó felkészültségérôl és becsüløtes emberségérôl - hogy a: doligozat kémiai része a kor szinषonalán áll és a vizsgálat

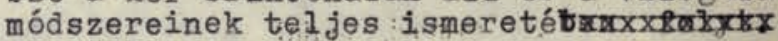
tükrözi.

A téma időszerüségérô̋. Régészetünk a "humán" módszerek tekintetében világszinvonalu, de állandóan érezzük, $h \cap g y$ természettudoményos részrổl,kiūnösen a kémia oldaláról nem kapunk olyan segitséget,mint a külföldi kollégák.

Nos ebben kivétel a szerzố, akinek kémiai mérnöki oklevele van s azonkiv ül elvẻgez te ëgyetemünkön a régészeti szakot is. $\mathbb{R}_{i-}$ váló munkakészsége és tehetsége megbecsülést biztositott számára már hallgató korában is.

Mi az,ami ebben a dolozatában előreviszi régészet-tudományunak? Rgyre inkább látjuk, hogy a. kéôs-avar/onogur/ népnél az ôv nek nemcsak tartó szerepe volt, hanem a szabad ember jelképe volt és a rajta lévổ veretek mintái nem csupán müvészi kedv telés eredményei, hanem rang-és méltóságlezôk, a veretek számф sem-këzömbös. Nos lezôk, a veretek szamq sem-kézommós hogy egy ôv vereteit egyszerre szerelték - e rá az ôvre, łagy pedig egymásután kapta meg viselőjük a magasabb s magasabb rangjăt $s$ ennek megfelelb́en a verebk száma nótt. Izt külső szemlélettel eldönteni nagyon nehéz, bár látjuk, hogy az egyes veretek mintáfiban kisebb eltérések vannak, tehát nem keriulihettek ki ugyanabból az ontốmintából. De itt a döntố szó az a nyag összetétele. Ugyancsak döntô a felerósilö szögescek anyaganak ensotelo.

Nos éppen ezeket a kérdéseket vizsgálja Költỗ László -s ezzel teljesen uj eredményeket és uj utakat nyit régészetünkben. Iz a birálat nem tüzheti ki aljául az eredmények pészletes bemutatás $t, \theta z$ rész. letkérdés." magam részéről ugy látom, hog még egy aprósággal kiegészithetók a vizs. gálatok bár ez nem az anyagot illeti s igy ebben a kitünô doktori értekezésben nincsen is keresni valója. $x_{z}$ pedig az ôv veretek felerốsitése közben szenvedett esetleges torzulások, horpatsok vizsgálata.Az érzékeny araôvvereteket pántokkal iátták el. s ezeket átdugva a bốrbe v vágott réseken, hátul összefüzték, am.jd $¥ \mathbb{z}$ egész bvet egy belsổ boritó szijjal takarták. Máśnhol az egész veretet átfogó kengyeit forrasztattak a veterekre $\mathrm{s}$ ugy huzták rá a szijakra.Amit Költổ 

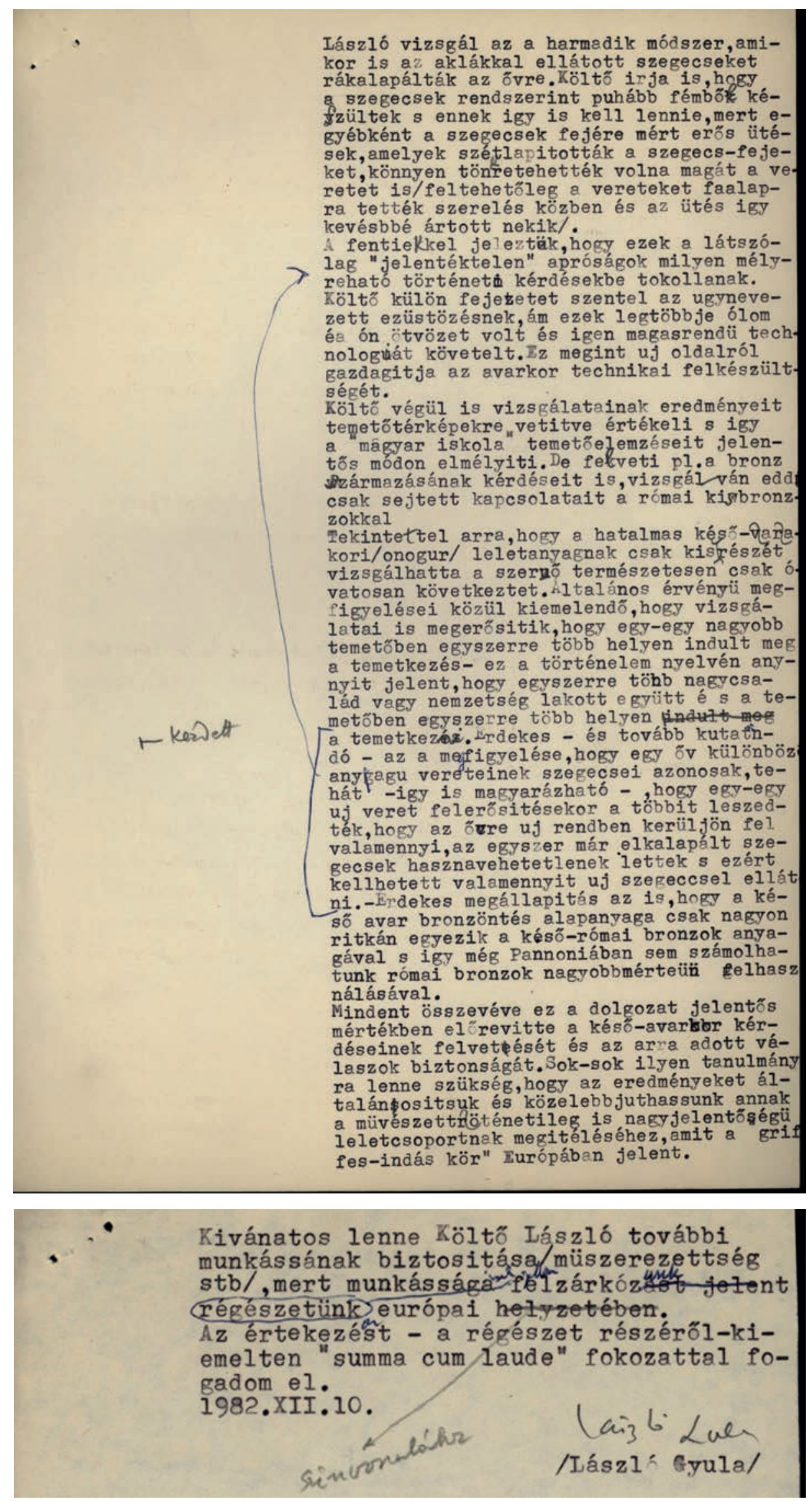